\title{
The Impact Of A Cohort Model Learning Community On First-Year Engineering Student Success
}

\author{
Toni L. Doolen, Oregon State University, USA \\ Erin Biddlecombe, Talent Pipeline, lululemon athletic, Canada
}

\begin{abstract}
This study investigated the effect of cohort participation in a learning community and collaborative learning techniques on the success of first-year engineering students. Student success was measured as gains in knowledge, skills, and attitudes, student engagement, and persistence in engineering. The study group was comprised of students registered in an engineering orientation course. Two sub-groups were compared: a) a test cohort and b) a control group. Students registered in the test cohort shared four courses. The control group shared only one course, an engineering orientation course. An exit survey was used to measure gains in skills and attitudes, student engagement, and student perceptions of collaborative learning techniques. Participation in the learning community test cohort was not found to improve student success. Participation in the learning community test cohort model was, however, linked to more positive student attitudes towards engineering and higher levels of student satisfaction with the collaborative learning techniques used in the course.
\end{abstract}

Keywords: Learning Community; Collaborative Learning Engineering Orientation; Student Success; First-Year Students

\section{INTRODUCTION}

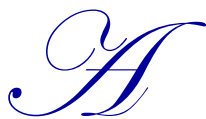

study by Astin (1997) concluded that majoring in engineering correlated negatively with student satisfaction. Specifically, engineering majors were less satisfied with the quality of their instruction and overall college experience than students in other majors. In addition, engineering students felt more overwhelmed and depressed than their non-engineering peers. "Clearly, these findings indicate that the climate characterizing the typical institution with a strong emphasis on engineering is not ideal for student learning and personal development" (Astin, 1997, pp. 360-361). Other sources support Astin's report, citing that engineering students are dissatisfied with their learning environments (Pascarella \& Terenzini, 2005; Rompelman, 2000).

Based on previous research, there appears to be a need for engineering educators to seek out and implement curricular strategies that encourage and support student learning. Education research indicates that in order to maximize student learning, educators must move away from more traditional lecture-based methods of teaching towards more engaging and student-centered approaches (Kuh, 1996; Pascarella, Springer, Terenzini, \& Nora, 1995). There is some evidence that this paradigm shift is occurring within engineering education. For example, ABET's outcomes-based approach to evaluating engineering programs nationwide has shifted emphasis towards student learning and competencies (Volkwein et al., 2004; Engineering Accreditation Commission, 2007). This is in contrast to the previous ABET accreditation process, which was prescriptive and focused primarily on determining if programs contained sufficient numbers and types of courses, and one where student grades were used as the primary evidence of student learning (Yeargan, 2003). With the new criteria, programs must demonstrate that processes to continuously improve programs have been implemented. Additionally, programs must utilize assessment and evaluation processes to monitor and take steps towards improving outcomes at the student, course, and program levels. Educators cannot, however, rely solely on progress resulting in a response to accreditation requirements. Instead, educators must recognize their role in promoting student learning. 
An overview of education research evidences the relationship between innovative teaching techniques and an increase in student learning and success. More specifically, students will learn more when the classroom is engaging, and when students have the opportunity to interact with their instructor and peers (Astin, 1993; Mazumder, 2010; Pascarella \& Terenzini, 2005; Tinto, 1987). Student learning can be augmented when students are involved in the process of knowledge acquisition; for example, via active learning projects (Astin, 1985; Kuh, 2003). This study sought to integrate findings from previous educational research in an effort to improve the success of engineering students at Oregon State University (OSU). In particular, the College of Engineering created a common first year schedule for a test cohort of first-year engineering students.

The general engineering orientation course at OSU, Engineering 111 (ENGR 111), piloted a cohort model as a means for improving student success through interventions focused on increasing student learning, engagement, and persistence. One section of students (the test cohort) enrolled in ENGR 111 was registered into a common set of classes. The students were also registered in the same sections of all lectures, recitations, and laboratories. Success of students in the test cohort was compared with the success of all other students taking ENGR 111 in the same term as the control group.

In this course, collaborative learning techniques were employed by the course instructor and teaching assistants. Testing was completed to determine whether or not these collaborative learning techniques were viewed more positively by cohort participants as compared to the control group participants. A review of the literature was used to guide the construction of the hypotheses tested in this study.

\section{REVIEW OF THE LITERATURE}

Three primary areas of previous research were used in developing the hypotheses for this study. These areas include: a) factors that affect student success, b) cohort-model learning communities, and c) collaborative learning.

\section{Factors Affecting Student Success}

Education research indicates that a key factor in college student success is student engagement (Astin, 1977, 1985; Chickering \& Gamson, 1987; Chickering \& Reisser, 1993; Feldman \& Newcomb, 1969; Kuh, 2001; Pace, 1979; Sanford, 1967). The definition of "student engagement" is based on two tenets. The first tenet is student-dependent: the amount of time and effort invested by a student in academic pursuits influences this student's engagement. That is, student engagement is a measure of a student's quantified commitment as well as the student's quality of effort. For example, a student who commits to regularly reviewing course materials and lecture notes, to thoroughly completing weekly problem sets, and/or to studying with peers is considered to be engaged. The second tenet is institution-dependent: how an institution chooses to allocate resources and organize the curriculum influences student engagement. Institutions that create curricular opportunities to induce student participation will improve student success and subsequently, will graduate engaged students. Schools who offer student-centered approaches to learning will engage students more than peer institutions that cling to traditional pedagogies of teaching. Some examples of these approaches to learning include: learning communities, experiential learning opportunities, and collaborative learning environments (Kuh, 2003).

A second factor that affects first-year student success is student interaction with others, including peers and faculty members. According to Astin (1997), "The student's peer group is the single most potent source of influence on growth and development during the undergraduate years" (p. 398). The development of strong peer relationships is significant for both student social and academic support. Pascarella and Terenzini (2005) reviewed related evidence on students' interactions with their peers and concluded that the frequency and the quality of student exchanges with peers were both positively associated with student success and persistence. At the same time, first-year student success was positively related to the quantity of student-faculty non-curricular interactions (those interactions taking place outside of the formal student-faculty relationship) and the regularity of studentfaculty interactions to discuss academic matters (Pascarella \& Terenzini, 2005; Cui et al., 2011). Lundquist, Spalding, and Landrum (2003) found that the following faculty behaviors contributed to student success: a) accommodating of student needs, b) in-person approachability, and c) accessibility to students via telephone and email. 


\section{Models of Learning Communities}

A learning community can be defined as an intentional linkage or cluster of two or more courses, often around an interdisciplinary theme or problem, which enrolls a common cohort of students (Shapiro \& Levine, 1999; Thompson, Oakes, \& Bodner, 2005). Learning communities can range from scheduling groups of students to share two or more courses, to grouping students into a cohort and housing this cohort of students in the same residence hall. The most common form is the clustered course approach whereby students are linked together via common courses and a blocked schedule. In this model, the cohort is generally comprised of 20-30 students (Smith, MacGregor, Matthews, \& Gabelnick, 2004). One course tends to be a writing course, and the cluster usually includes a weekly seminar. The weekly seminar plays an important role in helping students and faculty build connections in a smaller learning environment (Laufgraben, 2003).

Fundamental outcomes of a learning community include: a) frequent faculty-student interaction, b) frequent student-student interaction, and c) time devoted to studying and collaborative learning opportunities (Laufgraben, 2003). These intentionally-interactive small group environments assist the establishment of academic and social support networks inside and outside of the classroom (Collison, 1993; Davies et al., 2005; Laufgraben, 2003; MacGregor, Smith, Matthews, \& Gabelnick, 1997). Collaborative learning, an integral part of the learning community, has also been shown to promote student success (Crissman, 2001; Gabelnick, Macgregor, Matthews, \& Smith, 1999; Schroeder, 1994; Shapiro \& Levine, 1999; Tinto \& Goodsell Love, 1995; Tinto, Goodsell Love, \& Russo, 1993).

Education studies reveal that learning communities facilitate first year student adaptation to the college classroom environment (Castro-Cedeno, 2005; Kuh, 1996). The learning community environment provides an ideal setting in which to introduce students to the academic expectations and rigor of the college classroom, while student interaction with peers reinforces the attitudes essential to succeed as an engaged member of this community (Smith, MacGregor, Matthews, \& Gabelnick, 2004). Student participants in the learning community are more likely to contribute in class discussions, to raise questions, and to seek an instructor's help than non-participant peers. These students report greater satisfaction with courses and professors, and are more likely to participate in academic and social activities (Reumann-Moore, El-Haj, \& Gold, 1997; Tinto, Goodsell Love, \& Russo, 1993).

\section{Collaborative Learning}

There has been much published on the need for student-centered instruction. One approach to studentcentered instruction is collaborative learning. Collaborative learning environments are characterized by students working together to reach a common academic goal (Ge, 2012). In this way, students master knowledge by constructing it. Collaborative learning techniques can utilize a variety of formats, technologies, as well as small and large groups of students. Examples of the collaborative learning techniques include, collaborative writing, group case study work, and group design projects (MacGregor, 1990).

Proponents of collaborative learning maintain that the active exchange of ideas within small groups of students not only increases interest of the students, but also encourages critical thinking (Beckman, 1990). Johnson and Johnson (1986) suggest that cooperative teams function at higher levels of thought and retain information longer than students who work as individuals. The shared learning experienced via collaborative learning gives students the opportunity to engage in dialogue, take responsibility for their own learning, and thus develop critical thinking skills (Totten, Sills, Digby, \& Russ, 1991).

In addition, collaborative learning can also result in social benefits to the students, including developing students' ability to view situations from others' perspectives and the creation of social support systems (MacGregor, 1990). Psychologically, collaborative learning has been shown to result in reduced classroom anxiety and increased student satisfaction. 


\section{METHODOLOGY}

\section{Research Model}

This study sought to determine whether or not student participation in a learning cohort positively affected student success in a course where collaborative learning techniques were applied. Post-hoc analysis was also completed to study whether or not student demographics could account for any observed differences. The research model developed to guide this study is shown in Figure 1.

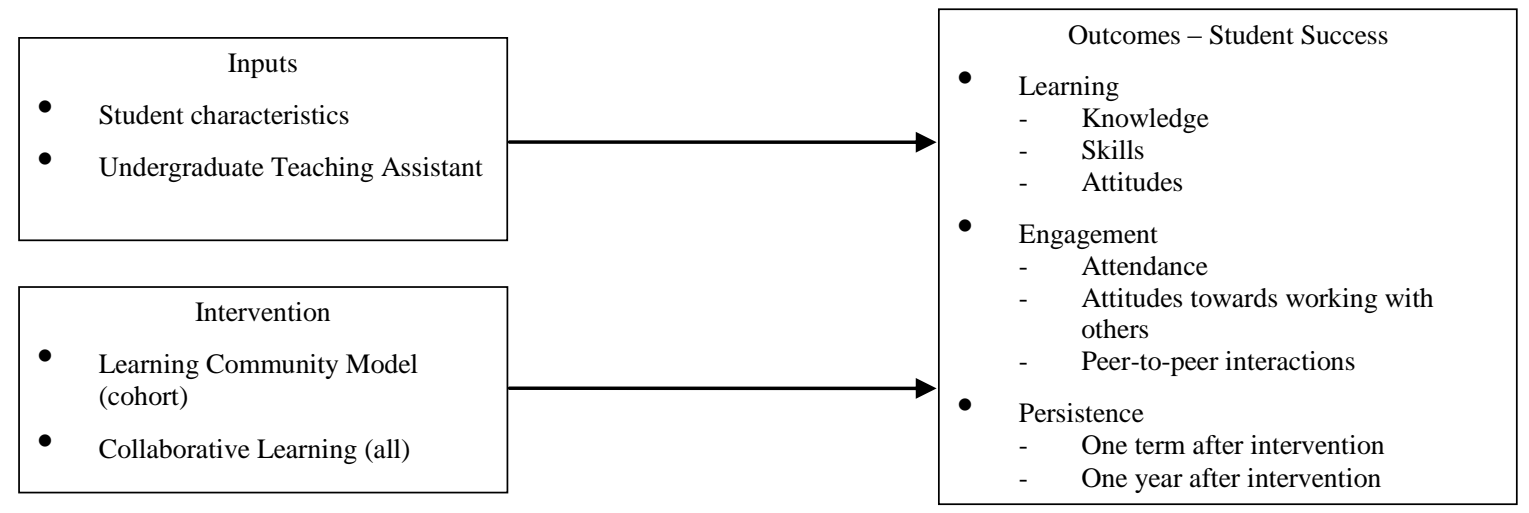

Figure 1: Research Model

Eight different hypotheses were tested in the study and are summarized in Table 1. Student success was measured by evaluating student learning, engagement, and persistence. Student learning was evaluated through an assessment of gains in knowledge and skills and through assessing student attitudes regarding engineering as a discipline. Gains in knowledge were measured through the analysis of student coursework in ENGR 111 and cumulative OSU GPAs. Gains in skills were measured using an assessment of the development of study skills. Student engagement was measured through an evaluation of participation in ENGR 111, as measured by attendance and by assessing attitudes towards working with others, as well as peer-to-peer interactions. Persistence was measured by looking at whether or not students were enrolled in the engineering program at two points in time - one term after the intervention and one year after the intervention. Post hoc testing was completed to determine if uncontrolled inputs (student demographics or undergraduate teaching assistant) could provide alternate explanations for any identified, significant differences.

Table 1: Research Hypotheses for ENGR 111 Cohort Study

\begin{tabular}{|c|c|c|}
\hline Input Variable & Null Hypothesis & Alternate Hypothesis \\
\hline Knowledge (K) & $\begin{array}{l}\mathrm{H}_{10} \text { Student participation in a learning cohort is } \\
\text { not correlated to student GPA and course } \\
\text { performance. }\end{array}$ & $\begin{array}{l}\mathrm{H}_{1 \mathrm{a}} \text { Student participation in a learning cohort is } \\
\text { positively correlated to student GPA and } \\
\text { course performance. }\end{array}$ \\
\hline Skills (S) & $\begin{array}{c}\mathrm{H}_{2 \mathrm{o}} \text { Student participation in a learning cohort is } \\
\text { not correlated to effective study skills. }\end{array}$ & $\begin{array}{c}\mathrm{H}_{2 \mathrm{a}} \begin{array}{l}\text { Student participation in a learning cohort is } \\
\text { positively correlated to effective study skills. }\end{array} \\
\end{array}$ \\
\hline Attitudes (A) & $\begin{array}{l}\mathrm{H}_{30} \text { Student participation in a learning cohort is } \\
\text { not correlated to student attitudes towards } \\
\text { the discipline of engineering. }\end{array}$ & 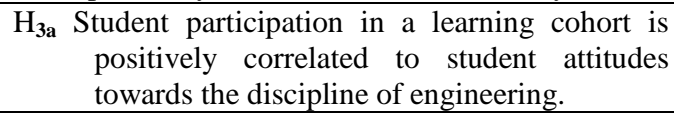 \\
\hline Engagement (E) & $\begin{array}{l}\mathrm{H}_{40} \text { Student participation in a learning cohort is } \\
\text { not correlated to attendance scores in } \\
\text { ENGR 111. } \\
\mathrm{H}_{50} \text { Student participation in a learning cohort is } \\
\text { not correlated to student attitudes towards } \\
\text { working with others. } \\
\mathrm{H}_{60} \text { Student participation in a learning cohort is } \\
\text { not correlated to the level of student to } \\
\text { student interaction. }\end{array}$ & $\begin{array}{l}\mathrm{H}_{4 \mathrm{a}} \begin{array}{l}\text { Student participation in a learning cohort is } \\
\text { positively correlated to higher attendance } \\
\text { scores in ENGR } 111 \text {. }\end{array} \\
\mathrm{H}_{5 \mathrm{a}} \text { Student participation in a learning cohort is } \\
\text { positively correlated to student attitudes } \\
\text { towards working with others. } \\
\mathrm{H}_{6 \mathrm{a}} \text { Student participation in a learning cohort is } \\
\text { positively correlated to an increased level of } \\
\text { student to student interaction. }\end{array}$ \\
\hline
\end{tabular}


Table 1 cont.

\begin{tabular}{|l|c|c|}
\hline $\begin{array}{l}\text { Collaborative } \\
\text { Learning (CL) }\end{array}$ & $\begin{array}{c}\mathrm{H}_{\mathbf{7 0}} \text { Student participation in a learning cohort is } \\
\text { not correlated to student evaluation of the } \\
\text { collaborative learning techniques. }\end{array}$ & $\begin{array}{c}\mathrm{H}_{\mathbf{7 a}} \\
\begin{array}{c}\text { Student participation in a learning cohort is } \\
\text { positively correlated to student evaluation of } \\
\text { collaborative learning techniques. }\end{array}\end{array}$ \\
\hline Persistence (P) & $\begin{array}{c}\mathrm{H}_{\mathbf{8}} \text { Student participation in a learning cohort is } \\
\text { not correlated to continued enrollment in } \\
\text { the engineering program. }\end{array}$ & $\begin{array}{c}\mathrm{H}_{\mathbf{8 a}} \\
\text { Student participation in a learning cohort is } \\
\text { positively correlated to continued enrollment } \\
\text { in the engineering program. }\end{array}$ \\
\hline
\end{tabular}

\section{Course Description}

Engineering 111, Engineering Orientation I, is a ten-week, 3-credit first-year course designed for preengineering students who have not yet chosen a particular engineering major. This course is intended to give students a broad introduction to the profession and disciplines of engineering. Emphasis is placed on the application of engineering and design concepts to generate solutions to engineering-based problems. There are no pre-requisites for the course. Students declaring the pre-engineering major of "General Engineering" at OSU are required to take Engineering 111. The number of students who completed the fall term course during the study was 123 students. Student grades were assigned based on attendance, homework, a team design project, a midterm exam, and a final exam. Each of these elements was assessed out of 100 points and accounted for $20 \%$ of the student's final course grade.

The Engineering 111 curriculum was delivered via three teaching environments: a) lecture, b) laboratory, and c) recitation. Students attended the lectures, labs, and recitations weekly. The 50-minute lecture included guest speakers from different engineering disciplines as well as instruction on engineering design and project management. Lectures were either delivered by or facilitated by the course instructor. While all students attended the lecture together, students were divided into smaller groups $(n=18$ to 23) and met twice a week for a two-hour laboratory and a two-hour recitation. Each laboratory session focused on experiments from the various engineering disciplines, in conjunction with the discipline presented during lecture that particular week. The recitations covered various academic success topics, engineering ethics and professionalism, and technical topics, including dimensional analysis and correctly using of significant digits. Recitation topics and some of the learning techniques, including collaborative learning techniques, used through the term are summarized in Table 2.

Table 2: Learning Activities used during ENGR 111 Recitations

\begin{tabular}{|c|c|}
\hline Week Recitation Topic & Sample of Learning Activities \\
\hline 1 - Managing the transition to OSU & $\begin{array}{ll}\text { - } & \text { One minute paper on "First impressions of college" } \\
\text { - } & \text { High school vs. university differences group activity } \\
\text { - } & \text { Develop questions for student panel for lecture in week } 2 \\
\text { - } & \text { Review and discussion of laboratory notebook requirements }\end{array}$ \\
\hline 2 - Classroom success & $\begin{array}{l}\text { - One minute paper on "How to get the most out of my classes" } \\
\text { - Library tour } \\
\text { - } \quad \text { Class note comparison activity }\end{array}$ \\
\hline $\begin{array}{l}3 \text { - Choosing a major and selecting classes \& } \\
\text { representing technical information }\end{array}$ & $\begin{array}{l}\text { - } \text { One minute paper on "Questions I have about engineering majors" } \\
\text { - } \quad \text { Academic advisor presentation and Q\&A } \\
\text { - } \quad \text { Presentation on using charts and graphs to present technical information }\end{array}$ \\
\hline $\begin{array}{l}4 \text { - Learning styles \& estimates and error } \\
\text { approximations }\end{array}$ & $\begin{array}{ll}\text { - } & \text { One minute paper on "How I learn best" } \\
\text { - } & \text { VARK learning style assessment and case study } \\
\text { - } & \text { Estimates and error approximation worksheet }\end{array}$ \\
\hline 5 - Managing your OSU workload & $\begin{array}{l}\text { - One minute paper on "Creating a plan for midterm success" } \\
\text { - } \quad \text { Academic Success Center presentation } \\
\text { - } \quad \text { Discussion of available student services } \\
\end{array}$ \\
\hline $\begin{array}{l}6 \text { - Balancing it all \& measurement units and } \\
\text { conversions }\end{array}$ & $\begin{array}{ll}\text { - } & \text { Self-reflection of student midterm performance } \\
\text { - } & \text { One minute paper on "Coping with stress" } \\
\text { - } & \text { Peer Health Educators talk on balance and stress management } \\
\text { - } & \text { Units and conversions worksheet }\end{array}$ \\
\hline 7 - Working on Engineering teams & $\begin{array}{ll}\text { - } & \text { One minute paper on "Making teams successful" } \\
\text { - } & \text { Meyers Briggs Type Indicator assessment and discussion } \\
\text { - } & \text { Discussion of course planning for next term } \\
\text { - } & \text { Diversity of Species activity }\end{array}$ \\
\hline
\end{tabular}


Table 2 cont.

\begin{tabular}{|l|l|}
\hline 8 - Team Projects & $\begin{array}{l}- \text { Check in on team project status } \\
- \text { Time to work on team projects }\end{array}$ \\
\hline 9 & Thanksgiving break \\
\hline $\begin{array}{l}10 \text { - Engineering ethics and professionalism \& } \\
\text { wrap up }\end{array}$ & $\begin{array}{l}- \text { Engineering ethics presentation } \\
- \text { Discussion and completion of engineering ethics worksheet on Bhopal } \\
\text { case study }\end{array}$ \\
\hline
\end{tabular}

Six undergraduate teaching assistants were employed to teach the laboratory and recitation sections of this course. Research supports the decision to use undergraduate teaching assistants, as peer instruction has been found to be a more effective learning tool than instructor-led learning (McCreary Golde, \& Koeskie, 2006). Five of the six teaching assistants were senior Industrial Engineering students; the sixth assistant was a senior in Chemical Engineering. The Industrial Engineering students were all male, while the one Chemical Engineering student was female. Undergraduate teaching assistants were recruited for this role based on their ability to communicate effectively and lead peer groups.

Each teaching assistant was responsible for teaching the same group of students for the duration of the term. In addition to leading the weekly laboratory and recitation sessions, each teaching assistant was responsible for taking attendance and grading homework and tests. Teaching assistants were trained before the start of the term on relevant topics including professionalism, teaching methodology, and diversity awareness. Specific lesson plans were developed and used for both recitation and laboratory sessions each week. During the term, teaching assistants trained weekly with the instructor and a graduate student in the College of Education's College Student Services Administration program on the materials that would be covered in the upcoming week's laboratory and recitation.

\section{Research Variables}

Research by Hinton (1993) concludes that classroom instruments that are based on student perceptions of the efficacy of teaching and learning methods are both valid and reliable. Such instruments provide robust information on student perceptions of learning-more so than typical course evaluations, which show little useful information related to teaching pedagogy or student learning. More specifically, traditional course evaluations serve to tell instructors what students "liked" about the course, but tells little about what the student gained from their participation in a class (Seymour, Wiese, Hunter, \& Daffinrud, 2000).

An existing online survey, the Student Assessment of Learning Gains (SALG), was used to assess student skills, attitudes engagement, and student perceptions of the collaborative learning elements used in ENGR 111. The SALG was developed by Seymour, Wiese, Hunter, \& Daffinrud at the University of Colorado at Boulder (2000). This instrument measures student perceptions of learning gains made in relation to specific components of a course. More specifically, the following types of gains can be explored: skill development, cognition, attitudes, and learning retention. Thus, the SALG instrument can be used to provide feedback on student learning gains in relationship to a specific course or series of courses. The hosting website allows customization of the instrument. The standard set of items can be modified, added, or deleted. The instrument's website is also used for survey administration and to store student responses. Data from completed surveys can be downloaded into other software packages for additional manipulation and analysis (Seymour, 2006).

The SALG survey, customized for ENGR 111, contained 56 items divided into six sections. A five-point Likert scale was used for all items. The first section focused on the impact of different course elements on student learning; e.g., class activities, homework assignments, exams, textbooks. The second section of the survey centered on gains in engineering-specific knowledge; e.g., understanding of unit conversion and dimensional analysis, understanding of the engineering design process, etc. The third section included items related to the development of study skills; e.g., managing time, taking effective notes, using campus resources, etc. The fourth section included items relating to broader capabilities related to success in academia and in engineering; e.g., feeling comfortable with complex ideas, ability to think through problems, etc. The items in the fifth section probed whether or not students felt that elements of the course would be pertinent to other classes or in other aspects of the student's life; e.g., study skills, working effectively in groups, problem solving abilities, etc. 
The sixth and final section consisted of items asking students to evaluate how strongly students felt about educational goals, such as graduating from college and completing studies in engineering. This section also included items asking students to assess whether or not students had developed relationships with faculty and peers to help them be successful. A summary of the survey items used for to measure skills (S), attitudes (A), student engagement (E2 and E3), and collaborative learning (CL) are summarized in Table 3.

Table 3: SALG Items Used to Assess Student Success

\begin{tabular}{|c|c|}
\hline $\begin{array}{l}\text { Variable Name } \\
\text { Variable Description } \\
\text { (Cronbach's Alpha) }\end{array}$ & SALG Items \\
\hline Skills (S) & $\begin{array}{l}\text { Q3. "How much has this class added to your skills in each of the following?" } \\
\text { Q3.1: Studying effectively }\end{array}$ \\
\hline $\begin{array}{l}\text { Ability to study and use the } \\
\text { resources available on campus } \\
\text { effectively }\end{array}$ & $\begin{array}{l}\text { Q3.2: Taking effective notes } \\
\text { Q3.3: Understanding my learning style } \\
\text { Q3.4: Managing my time effectively } \\
\text { Q3.5: Using campus resources }\end{array}$ \\
\hline 0.891 & Q3.6: Understanding what is expected of me as a university student \\
\hline Attitude (A) & $\begin{array}{l}\text { Q4. "To what extent did you make gains in any of the following as a result of what you did } \\
\text { in this class?" }\end{array}$ \\
\hline $\begin{array}{l}\text { Attitudes toward the } \\
\text { engineering discipline }\end{array}$ & $\begin{array}{l}\text { Q4.5: Understanding the value of engineering in solving real world issues } \\
\text { Q4.6: Appreciating engineering as a discipline } \\
\text { Q4.7: Enthusiasm for engineering }\end{array}$ \\
\hline 0.873 & Q4.8: Confidence in my ability to be successful in my engineering studies \\
\hline Engagement (E2) & $\begin{array}{l}\text { Q3. "How much has this class added to your skills in each of the following?" } \\
\text { Q3.7: Working effectively with others }\end{array}$ \\
\hline $\begin{array}{l}\text { Attitude toward working with } \\
\text { others } \\
0.868\end{array}$ & $\begin{array}{l}\text { Q5. "How much of the following do you think you will remember and carry with you into } \\
\text { other classes or aspects of your life?" } \\
\text { Q5.5: Working effectively with others to study } \\
\text { Q5.6: Working effectively in groups on projects }\end{array}$ \\
\hline $\begin{array}{l}\text { Peer-to-peer interactions } \\
0.823\end{array}$ & $\begin{array}{l}\text { Q1H. "How much did each of the following aspects of the class help your learning? } \\
\text { Q1H2: Working with peers during labs and recitation } \\
\text { Q1H3: Working with peers outside of class } \\
\text { Q1H4: Studying with my peers }\end{array}$ \\
\hline Collaborative Learning (CL) & $\begin{array}{l}\text { Q1. How much did each of the following aspects of the class help your learning? } \\
\text { Q1.D2: Recitation activities }\end{array}$ \\
\hline $\begin{array}{l}\text { Course activities including } \\
\text { collaborative elements }\end{array}$ & $\begin{array}{l}\text { Q1.D3: Lab activities } \\
\text { Q1.E3: The team design project } \\
\text { Q1.H1: Interactions with my lab/recitation TA }\end{array}$ \\
\hline 0.813 & Q1.H2: Working with peers during labs and recitations \\
\hline
\end{tabular}

The remaining outcome variables were not measured using the SALG. The variable, knowledge (K), was measured using two different data sets. First, cumulative OSU GPA's at the end of the second term of enrollment at OSU were collected. Second, detailed student coursework performance data was collected from the instructor's course records. Scores for eight homework assignments, a midterm exam, a final exam, and a design project were used to provide an independent measure of student knowledge. Student attendance scores were also collected from the instructor's course records. This data was used to provide another measure of student engagement (E1). The final variable, not measured using the SALG was persistence. Persistence $(\mathrm{P})$ was measured using student enrollment status one term and again one year after the intervention. Student demographic data from the university data warehouse was also collected for each student enrolled in ENGR 111.

\section{Participants}

Institutional Review Board (IRB) permission was sought and obtained for this study. Students were asked to join the learning community cohort during the summer orientation and registration session, after determining that students were also planning to take Calculus (MTH 251) and first-year Chemistry (CHEM 201). The only incentive for joining the cohort was being able to take Public Speaking (COMM 111) in the first term of their first year. This 
class is typically filled by upper division students, making it difficult for first year students (who register last) to find an open slot. In total, students registered in the test cohort shared four courses in the Fall term, including first year Chemistry (CHEM 201), Public Speaking (COMM 111), Calculus (MTH 251), and Engineering Orientation (ENGR 111). Control group student schedules included Engineering Orientation (ENGR 111) and other courses typical to a first-year engineering student; e.g., math, chemistry, writing, and/or health. No attempts were made to organize control group student schedules.

All ENGR 111 students were given the opportunity to complete the SALG survey. Participation was voluntary. The survey was administered in recitations during the last week of the academic term. The undergraduate teaching assistants distributed instructions for completing the on-line survey and read a script informing students about the survey, along with their rights as study participants. Students were permitted to ask questions prior to determining whether or not to participate. Using a course ID and password provided by the teaching assistants, students logged in and completed the online survey. This process required approximately 10 to 15 minutes of time.

A total of 96 students chose to complete the SALG. This corresponds to a response rate of $78 \%$. In total, 20 students were registered into the test cohort. All test cohort participants were male. Of the 20 registered in the test cohort, 13 completed the SALG. Thus, the remaining 83 responses represented control group participants from the five other sections. SALG data was collected by recitation, enabling comparisons between the test cohort and either the entire group of control participants or comparison to individual sections within the control group.

To maintain anonymity, demographic data specific to the group of students who chose to complete the SALG was not collected. Demographic data for all ENGR 111 students was available, however, from the university data warehouse. $81 \%$ of the students were male and $19 \%$ were female. White, non-Hispanic students made up $75 \%$ of the student population, while $15 \%$ were Asian. The third group consisted of ethnicities typically underrepresented in engineering including Hispanic, African-American, and Native Indian students. This combined group of students made up 10\% of the ENGR 111 student population. Students from rural locations made up 40\% of the student population in ENGR 111, while the remaining 60\% came from urban areas.

\section{RESULTS}

Data analysis for this study was conducted using SPSS 15.0. Three different data sources were used in completing the analysis and in testing the seven research hypotheses: the SALG responses, the university data warehouse (cumulative GPAs, demographic data, and student enrollments), and the instructor's course records. The analyses used for the various data sets are described and the results from these analyses are summarized in this section.

The number of responses, means, and standard deviations for each of the five outcomes variables measured using the SALG, as well as student assessment of the collaborative learning elements in the course are summarized in Table 4. The number of SALG responses used for determining means and standard deviations varied slightly due to incomplete surveys. If a student did not complete all items for one of the variables, the data for that variable from that student was not used in the analysis. Reliability coefficients (Cronbach's Alpha) were calculated for the five variables created from a subset of SALG items (S, A, E2, E3, and CL). Cronbach alpha values for each of these variables are included in Table 3. A Cronbach's alpha of at least 0.7 is considered to provide evidence of a reliable scale. Based on this criterion, reliabilities were acceptable for all five variables constructed from SALG responses. Summary statistics for the outcome variables used to measure student knowledge (K1, K2, K3, K4, and K5) and student engagement as measured by attendance scores (E1) are also included in Table 4. The maximum possible GPA at OSU is a 4.00. The maximum possible score for each aspect of the course grade (homework, midterm exam, final exam, attendance, and design project) was 100. 
Table 4: Descriptive Statistics for Outcome Variables and Collaborative Learning

\begin{tabular}{|l|c|c|c|}
\hline \multicolumn{1}{|c|}{ Variable } & n & Mean & Std Dev \\
\hline S (Study skills) & 97 & 2.85 & 0.797 \\
\hline A (Attitudes towards the discipline of engineering) & 95 & 3.11 & 0.854 \\
\hline E1 (Engagement as measured by attendance scores) & 123 & 98.21 & 4.66 \\
\hline E2 (Attitudes towards working with others) & 97 & 3.28 & 0.866 \\
\hline E3 (Peer-to-peer interactions) & 97 & 3.40 & 0.830 \\
\hline CL (Collaborative Learning) & 97 & 3.33 & 0.760 \\
\hline K1 (Knowledge as measured by cumulative OSU GPA) & 118 & 2.94 & 0.759 \\
\hline K2 (Knowledge as measured by homework scores) & 123 & 86.39 & 12.48 \\
\hline K3 (Knowledge as measured by midterm exam scores) & 123 & 83.09 & 8.65 \\
\hline K4 (Knowledge as measured by final exam scores) & 123 & 81.86 & 10.54 \\
\hline K5 (Knowledge as measured by design project scores) & 123 & 92.32 & 3.99 \\
\hline
\end{tabular}

Having determined that the SALG responses demonstrated acceptable levels of reliability, additional analyses were completed to determine the appropriate tests to use for the research hypotheses. Results from Levene's test for equality of variances indicated that variances were not significantly different between the test cohort and control group for the variables S, A, E2, E3, CL, and OSU GPA. Evidence of non-equal variances was found, however, for homework (K2) and attendance scores (E1). The normality of the data was assessed for each variable using a one-sample Kolmogorov-Smirnov procedure and by evaluating Q-Q plots. There was evidence of non-normality for all variables created from the SALG data and for homework (K2) and attendance scores (E1). OSU GPA data, midterm exam scores, final exam scores, and design project scores were normally distributed. Nonparametric testing was used for all subsequent analyses, except in evaluating differences for OSU GPA's, midterm exam scores, final exam scores, and design project scores.

One sided tests were used for each hypothesis based on the evidence found during literature review supporting a positive relationship between learning communities as well as collaborative learning techniques and student success. Decisions on the statistical significance of results were made using an alpha $(\alpha)$ of 0.05 . Where significant differences were identified, post-hoc testing was conducted to determine the location of these differences. Post-hoc analysis of significant differences between groups was completed using Dunnett's test. Since the test cohort was compared against each section within the control group, an alpha of 0.01 was used to determine statistical significance, since five comparisons were performed. The results of the statistical analyses completed for each variable are summarized by hypothesis in Table 5. The type of test completed, the test statistic, and the p-value are included.

Table 5: Hypotheses Testing Results for $\mathrm{H}_{1}-\mathrm{H}_{7}$

\begin{tabular}{|l|l|c|c|c|}
\hline \multicolumn{1}{|c|}{ Hypothesis } & \multicolumn{1}{|c|}{ Variable } & Test type & Test Statistic* & p-value \\
\hline \multirow{4}{*}{$\mathrm{H}_{1}$} & K1 (Cumulative OSU GPA) & ANOVA & 1.12 & 0.352 \\
\cline { 2 - 5 } & K2 (Homework ) & Kruskal Wallis & 17.86 & 0.003 \\
\cline { 2 - 5 } & K3 (Midterm exam) & ANOVA & 0.95 & 0.453 \\
\cline { 2 - 5 } & K4 (Final exam) & ANOVA & 1.15 & 0.339 \\
\cline { 2 - 5 } & K5 (Design project) & ANOVA & 6.20 & 0.000 \\
\hline $\mathrm{H}_{2}$ & S (Study skills) & Kruskal Wallis & 4.78 & 0.311 \\
\hline $\mathrm{H}_{3}$ & A (Discipline of engineering) & Kruskal Wallis & 8.36 & 0.079 \\
\hline $\mathrm{H}_{4}$ & E1 (Attendance) & Kruskal Wallis & 16.71 & 0.005 \\
\hline $\mathrm{H}_{5}$ & E2 (Working with others) & Kruskal Wallis & 1.61 & 0.807 \\
\hline $\mathrm{H}_{6}$ & E3 (Peer-to-peer interactions) & Kruskal Wallis & 2.99 & 0.559 \\
\hline $\mathrm{H}_{7}$ & CL (Collaborative learning) & Kruskal Wallis & 13.99 & 0.007 \\
\hline
\end{tabular}

* F-statistic for ANOVA; Chi-Square for Kruskal Wallis

Four statistically significant relationships were identified. Based on this analysis, there is evidence for a relationship between which section students were enrolled in and two measures of knowledge acquisition (homework scores and design project scores), between section enrollment and one measure of student engagement (attendance scores) and between section enrollment and student evaluations of the impact of collaborative learning activities. Since different teaching assistants were used for each section of students, post hoc testing was completed to identify whether or not the test cohort differed from any specific sections within the control group. 
Post hoc testing of the design team project scores found that while differences existed between sections, these differences could not be explained by participation in the test cohort. Two of the sections within the control group performed worse on the design project than the remaining sections in the control group and the test cohort, but the test cohort performed similarly to all other sections. After taking into account the corrected significance level for multiple comparisons, it was not possible to detect significant differences by section for homework scores or student attendance. Results from post hoc testing did, however, indicate that the test cohort rated the impact of collaborative learning activities significantly higher than one of the five sections in the control group.

Since participation in the cohort could not fully explain the observed differences, further analysis was completed to determine whether or not student characteristics, such as gender or ethnicity, could explain the observed differences in homework scores, term project scores, or in student attendance. Using a Mann-Whitney test (nonparametric test for two independent samples), a significant difference $(\mathrm{p}=0.026)$ was identified for homework scores, when gender was taken into account. In particular, female students had higher homework scores than their male counterparts. ANOVA was used to test for significant differences in term project scores, accounting for gender. A significant difference $(\mathrm{p}<0.000)$ was found. Gender was not a significant factor in attendance scores.

A second set of post-hoc tests was conducted to determine whether or not ethnicity could potentially explain differences in homework scores, design project scores or student attendance. When the scores of students who are not traditionally represented in engineering (Native American, Hispanic, Latino, Alaskan Native, African American) were compared with the remaining students (White, Euro American, Non-Hispanic, Asian, and Asian American), students from the underrepresented groups had significantly lower homework and attendance scores $(\mathrm{p}=$ 0.003 and $\mathrm{p}=0.009$ ). Ethnicity, however, did not appear to be a significant factor in term project scores.

The final hypothesis, $\mathrm{H}_{8}$, was tested using the persistence data collected both one term after and again one year after the intervention. A cross tabulation of enrollment data is summarized in Table 6 . The percentage of students leaving engineering for the test cohort was $10 \%$ at both times. The percentage of students leaving engineering from the control group was 19\% one term after the intervention and $21 \%$ one year after the intervention. Fisher's Exact Test was performed to test for differences. No significant difference was found.

Table 6: Cross-Tabulation of Enrollment Data One Term and One Year after the Intervention

\begin{tabular}{|l|c|c|}
\hline One term after intervention & $\begin{array}{c}\text { Test } \\
\text { Cohort }\end{array}$ & $\begin{array}{c}\text { Control } \\
\text { Group }\end{array}$ \\
\hline Transferred out of engineering & 2 & 17 \\
\hline Remaining in engineering & 18 & 72 \\
\hline
\end{tabular}

\begin{tabular}{|l|c|c|}
\hline One year after intervention & $\begin{array}{c}\text { Test } \\
\text { Cohort }\end{array}$ & $\begin{array}{c}\text { Control } \\
\text { Group }\end{array}$ \\
\hline Transferred out of engineering & 2 & 19 \\
\hline Remaining in engineering & 18 & 70 \\
\hline
\end{tabular}

\section{DISCUSSION}

This study investigated whether student participation in a learning community affects student success as measured by learning, engagement, and persistence. The study results only identified one significant difference linked to participation in the learning community. Education literature indicates that more structured learning communities are tied more closely to student gains in learning (Gabelnick, MacGregor, Matthews, \& Smith, 1999). While ENGR 111 cohort participants did share a common first term schedule, the cohort was not represented in a formalized way to this student population. The rationale for the common schedule was not discussed with the cohort group, which may have limited the impact of the intervention, the common set of classes on these students.

Within the education literature there is also some discussion on the importance of the bridging or synthesis course as part of the learning community model. This bridging course is often designed to help students to make connections across different academic disciplines, supporting increased levels of student learning and engagement (Davies, Ramsay, Lindfield, \& Couperwaite, 2005; Gabelnick, MacGregor, Matthews, \& Smith, 1999). The ENGR 111 cohort model did not include a separate course to serve this purpose. The topics covered in the ENGR 111 laboratories and recitation, while touching on a variety of science and mathematical concepts did not specifically connect with content in other courses being taken by the participants; e.g. chemistry or calculus. It is possible that without this element, the full benefit of the learning community model is not realized. 
Another factor that may have impacted the results of this study is the individual undergraduate teaching assistants' teaching styles. The research of Gutwill and Seymour (1999) indicates that peer instructors can play a significant role in student learning. Two of the sections of students in the control group consistently scored course elements lower than the remaining four sections, including the test cohort. Students in these sections rated recitation activities, lab activities, the grading system, and laboratory handouts as less helpful than other students. Interestingly, these students also evaluated their interactions with the undergraduate TA lower, indicating that these students felt less positive about the role of the undergraduate TA in their learning. Observations of the six undergraduate teaching assistants in laboratory as well as recitation settings by the graduate teaching assistant and the instructor provided some evidence of differences in teaching styles. For example, some TAs used a lecturebased approach while other TAs included group discussion and other less formal methods of instruction. It is possible that these differences in teaching style are linked with student gains in learning as it has been evidenced that student-centered approaches to teaching, when compared to more traditional professor-centered methods, will facilitate student learning and success (Kuh, 1996; Pascarella, Springer, Terenzini, \& Nora, 1995). Due to the nature of the data, these results cannot be used to show causation, but the results do suggest that the undergraduate teaching assistant may play a significant role in student learning.

Based on the results of the post-hoc analysis, there was some evidence that demographic factors (gender and ethnicity) may be tied to student success, both in terms of knowledge and engagement. Since no members of the cohort group were female and only one member of the cohort was a member of a traditionally underrepresented group within engineering, it was not possible to test for interactions between these demographic factors, participation in the cohort, and student success. However, the findings do indicate the need for additional study. A larger study would be needed to determine if there are indeed interactions between demographic factors, cohort participation, and the various measures of student success.

Overall, students rated the recitation and laboratory course components as being highly supportive of their learning. Student feedback regarding the non-traditional and small group interactions in the course was positive. The mean score of these items was higher than 3.0 on a 5.0 scale. A score of 3.0 corresponded to a qualitative statement of moderate help; whereas a score of 4.0 corresponded to a qualitative rating of much help. So while it was not possible to directly correlate participation in the test cohort with gains in student learning, overall ratings indicate that students, both in and outside of the test cohort, felt positively about the collaborative learning elements in the course.

Participants in the test cohort rated the collaborative learning elements of the course as being more helpful to their learning than students in the control group. It is possible that student cohort participants, given the increased interaction time, were able to collaborate more effectively with their group members during recitations and laboratories, resulting in their increased rating for the role of collaborative learning on their own personal learning gains.

While the research hypotheses developed for this study were addressed, at least in a specific setting, additional research is needed to generalize these findings. The impact of institutional-specific characteristics, for example, could not be tested for, but is an interesting factor to explore in a multi-institutional study or through replicating this study using other institutions. In addition, the results of this study have also identified two potential questions for future research. While this study only considered a single test group, there was not strong evidence to support a positive correlation between participation in the learning community model used (a common core of classes) and increased student success. One question to be answered is what elements are required for a learning community of engineering students to support student success? Are, for example, synthesis or bridge courses critical in realizing the full benefits of learning communities? Further, the cohorts for this study were selected based on the common schedules rather than using a protocol for assignment. While there was no evidence to suggest that common schedules correlated to certain student characteristics, future studies could benefit from a more deliberate selection of students into cohorts.

Second, how significant is the role of teaching styles by peer instructors in rendering collaborative learning elements and learning communities more or less effective? Conducting studies within an actual educational setting presents a variety of challenges. While all efforts were taken to train the peer instructors for this study in exactly the 
same way, there was evidence that peer instructors created different learning environments and these environments appeared to be correlated with student performance. Additional testing must be done to further understand this relationship and may be useful in developing future training for peer instructors.

Education literature shows that students who have confidence in their abilities within their academic discipline will persist at higher rates than those who do not (Pascarella \& Terenzini, 2005). It is evidenced in literature and benchmarking that engineering schools across the United States struggle to retain their students to graduation (Castro-Cedeno, 2005). This study suggests that collaborative learning, and to a lesser extent, learning communities, may play a role in engineering student success. While there was not any indication in previous research that learning communities and collaborative learning are more or less effective in different disciplines, the results of this study do suggest that additional research is needed to more fully characterize the potential impact of these techniques on engineering student success. These results, along with recent academic conversations related to engineering curriculum development (Saunders et al., 2013), highlight the importance of deliberate design work to create compelling opportunities for student learning and thinking outside of traditional means for engaging engineering students in their own learning.

\section{ACKNOWLEDGEMENTS}

The authors wish to acknowledge the support of the William and Flora Hewlett Foundation Engineering Schools of the West Initiative in providing the resources and funding necessary for this research.

\section{AUTHOR INFORMATION}

Toni L. Doolen is the Dean of the University Honors College and a Professor in industrial engineering at Oregon State University. She received her BS in material science and electrical engineering from Cornell University, her MS in manufacturing systems engineering from Stanford University, and her Ph.D. in industrial engineering from Oregon State University. Her research is focused on organizational improvement and process improvement. She has 12 years of experience at Hewlett-Packard as an engineer and manager. E-mail: doolen@engr.orst.edu (Corresponding author)

Erin Biddlecombe works as a manager at Talent Pipeline at lululemon athletica. She holds a MEd in College Student Services Administration from Oregon State University and a BSc in Integrated Sciences (Cell Biology and Genetics, Physiology) from the University of British Columbia. She is a member of UBC's Academic Senate, and, prior to her current position, worked in Student Affairs supporting the learning and professional development of UBC’s Engineering undergraduates. E-mail: ebiddlecombe@lululemon.com

\section{REFERENCES}

1. Astin, A. (1977). Four critical years: Effects of college on beliefs, attitudes, \& knowledge. San Francisco: Jossey Bass.

2. Astin, A. (1985). Student involvement: A developmental theory for higher education. Journal of College Student Development, 40(5), 518-519.

3. Astin, A. (1993). What matters in college. Liberal Education, 79(4), 4-15.

4. Astin, A. (1997). What matters in college: Four critical years revisited. San Francisco: Jossey Bass.

5. Beckman, M. (1990) Collaborative learning: Preparation for the workplace and democracy. College Teaching, 38(4), 128-133.

6. Castro-Cedeno, M. H. (2005). A quantitative assessment of the benefit of a learning community environment. Proceedings of the ASEE/IEEE Frontiers in Education Conference, Indianapolis, Indiana.

7. Chickering, A. W., \& Gamson, Z. (1987). Seven principles for good practice in undergraduate education. AAHE Bulletin, 39, 16-21.

8. Chickering, A. W., \& Reisser, L. (1993). Education and identity ( $2^{\text {nd }}$ Ed). San Francisco: Jossey Bass.

9. Collison, M. (1993). Learning communities for all. Chronicle of Higher Education, 43(2), 34-38.

10. Crissman, J. L. (2001). Clustered and nonclustered first-year seminars: New students' first-semester experiences. Journal of the First Year Experience and Students in Transition, 13, 69-88. 
11. Cui, S., Wang, Y., Yang, Y. Nave, F. M., \& Harris, K. T. (2011), Connecting incoming freshmen with engineering through hands-on projects. American Journal of Engineering Education, 2(2), 31-42.

12. Davies, A., Ramsay, J., Lindfield, H., \& Couperthwaite, J. (2005). Building learning communities: Foundations for good practice. British Journal of Education Technology, 36(4), 615-628.

13. Engineering Accreditation System (2007). Criteria for accrediting engineering programs. Retrieved from http://www.abet.org/Linked\%20Documents-UPDATE/Criteria\%20and\%20PP/E001\%200708\%20EAC\%20Criteria\%2011-15-06.pdf

14. Feldman, K. A., \& Newcomb, T. M. (1969). The impact of college on students. San Francisco: Jossey Bass.

15. Gabelnick, F., MacGregor, J., Matthews, B. S., \& Smith, B. L. (1999). Learning communities: Creating connections among students, faculty, and disciplines. San Francisco: Jossey Bass.

16. Ge, C. (2012). Application of wikis with scaffolding structure in laboratory reporting. American Journal of Engineering Education, 3(2), 89-104.

17. Gutwill, J., \& Seymour, E. (1999). ModularChem and ChemLinks annual evaluation report. Presentation to the ModularChem National Visiting Committee, Berkeley, California.

18. Hinton, H. (1993). Reliability and validity of student evaluations: Testing models versus survey research models. Political Science and Politics, 562-569.

19. Johnson, R. T., \& Johnson, D. W. (1986). Action research: Cooperative learning in the science classroom. Science and Children, 24, 31-32.

20. Kuh, G. D. (1996). Guiding principles for creating seamless learning environments. Journal of College Development, 37(3), 135-148.

21. Kuh, G. D. (2001). College students today: Why we can't leave serendipity to chance. In P. Altbach, P. Gumport, \& B. Johnstone (Eds.), In defense of American higher education (pp. 277-303). Baltimore: Johns Hopkins University Press.

22. Kuh, G. D. (2003). What we're learning about student engagement from NSSE. Change, 35(2), $24-32$.

23. Laufgraben, J. L. (2003). Faculty development: Growing, reflecting, learning, and changing. In J. O'Connor \& others (Eds.), Learning communities in research universities (pp. 33-37). Olympia, WA: Evergreen State College, Washington Center for Improving the Quality of Undergraduate Education.

24. Lundquist, C. Spalding, R. J., \& Landrum R. E. (2003). College students' Thoughts about leaving the university: The impact of faculty attitudes and behaviors. Journal of College Student Retention, 4(2), 123133.

25. McCreary, C. L., Golde, M. F., \& Koeski, R. (2006). Peer instruction in the general chemistry laboratory: Assessment of student learning. Journal of Chemical Education, 83(5), 804-810.

26. MacGregor, J. (1990). Collaborative learning: Shared inquiry as a process of reform. New Directions for Teaching and Learning, 42, 19-30.

27. MacGregor, J., Smith, B. L., Matthews, R., \& Gabelnick, F. (1997). Learning community models. Proceedings of the National Conference on Higher Education, American Association of Higher Education, Washington, DC.

28. Mazumder, Q. H. (2010), Fostering passion among first year engineering students. American Journal of Engineering Education, 1(1), 21-34.

29. Pace, R. H. (1979). Measuring outcomes of college: Fifty years of findings and recommendations for the future. San Francisco: Jossey Bass.

30. Pascarella, E. T., Springer, L., Terenzini, P. T., \& Nora, A. (1995). Influences affecting the development of students' critical thinking skills. Research in Higher Education, 36(1), 23-39.

31. Pascarella, E. T., \& Terenzini, P. T. (2005). How college affects students: A third decade of research. San Francisco: Jossey Bass.

32. Reumann-Moore, E., El-Haj, A., \& Gold, E. (1997). Friends for school purposes: Learning communities and their role in building community at a large urban university. Philadelphia: Temple University.

33. Rompelman, O. (2000). Assessment of student learning: Evolution of objectives in engineering education and the consequences for assessment. European Journal of Engineering Education, 25(4), 339-350.

34. Sanford, N. (1967). Where colleges fail: A study of the student as a person. San Francisco: Jossey Bass.

35. Saunders, K., Brumm, T., Brooke, C., Mickelson, S., \& Freeman, S. (2013). Assessing student work to support curriculum development: An engineering case study. Learning Communities Research and Practice, 1(1), 1-16. 
36. Schroeder, C. C. (1994). Developing learning communities. In C. C. Schroeder \& P. Mable (Eds.), Realizing the potential of residence halls (pp. 165-189). San Francisco: Jossey Bass.

37. Seymour, E. (2006). Student assessment of learning gains: Instrument description. Retrieved from http://www.wcer.wisc.edu/salgains/instructor/SALGains.asp

38. Seymour, E., Wiese, D. J., Hunter, A., \& Daffinrud, S. M. (2000). Creating a better mousetrap: On-line student assessment of their learning gains. Proceedings of the National Meetings of the American Chemical Society Symposium, San Francisco, California.

39. Shapiro, N. S., \& Levine, J. H. (1999). Creating learning communities: A practical guide to winning support, organizing for change, and implementing programs. San Francisco: Jossey Bass.

40. Smith, B. L., MacGregor, J., Matthews, R., \& Gabelnick, F. (2004). Learning communities: Reforming undergraduate education. San Francisco: Jossey Bass.

41. Thompson, M., Oakes, W., \& Bodner, G. (2005). A qualitative investigation of students in a first-year engineering learning community. Proceedings of ASEE/IEEE Frontiers in Education Conference, Indianapolis, Indiana.

42. Tinto, V. (1987). Leaving college: Rethinking the causes and cures of student attrition. Chicago: University of Chicago Press.

43. Tinto, V., \& Goodsell Love, A. (1995). A longitudinal study of freshman interest groups at the University of Washington. University Park, PA: Pennsylvania State University, National Center on Postsecondary Teaching, Learning, \& Assessment.

44. Tinto, V., Goodsell Love, A., \& Russo, P. (1993). Building learning communities for new college students: A summary of research findings of the collaborative learning project. University Park, PA: National Center of Postsecondary Teaching, Learning, \& Assessment.

45. Totten, S., Sills, T., Digby, A., \& Russ, P. (1991). Cooperative learning: A guide to research. New York: Garland.

46. Volkwein, J. F., Lattuca, L. R., Terenzini, P. T., Strauss, L. C., \& Sukhbaatar, J. (2004). Engineering change: A study of EC2000. International Journal of Engineering Education, 20(3), 318-328.

47. Yeargan, J. R. (2003). ABET's EC2000 criteria - The model for outcomes-based accreditation criteria. The Interface, IEEE, 3, 1-3. 